\title{
Design and performance analysis of a photovoltaic water pumping system based on DC-DC boost converter and $B L D C$ motor
}

\author{
M. Benzaouia ${ }^{1}$, L.Bouselham ${ }^{1}$,B. Hajji ${ }^{1}$, A.M. Dubois ${ }^{2}$, A. Benslimane ${ }^{1}$, M. El Ouariachi ${ }^{3}$ \\ ${ }^{1}$ Renewable Energy, Embedded System and Data Processing Laboratory, National School of Applied Sciences, Mohamed First \\ University, Oujda, Morocco \\ ${ }^{2}$ GeePs (Group of electrical engineering - Paris), UMR CNRS 8507, CentraleSupéle \\ ${ }^{3}$ Laboratory of Electrical Engineering and Maintenance (LEEM), Higher School of Technology, Mohamed First University, Oujda, Morocco
}

\begin{abstract}
This paper presents the modeling, control and optimization of a photovoltaic water pumping system. The DC-DC boost converter is used as a mediator between a Solar Photovoltaic (SPV) array and the Voltage Source Inverter (VSI) to feed the brushless DC (BLDC) motor.A centrifugal pump is connected to this motor in order to use the water pumped afterwards tomultiple applications. Maximum Power Point Tracking (MPPT) control techniques play a vital role in efficiency improvement of photovoltaic (PV) systems. It is mainly used to extract maximum possible power of the $P V$ modules under any condition of solar irradiation. For this reason, $\mathrm{P} \& \mathrm{O}$ algorithm is used due to its high performance and its simplicity of implementation. The boost converter, over the various common DC-DC converters, offers many advantages in SPV based applications, such limiting the starting inrush current of the motors. Using a BLDC motor is found to be the best option because of its high efficiency, supreme reliability, better performance, and requires low maintenance, over a wide range of speeds. The considered model as well as the control strategy has been implemented in MATLAB/Simulink environment. The results show the effectiveness of the studied photovoltaic water pumping system.
\end{abstract}

Keywords- solar photovoltaic array, boost converter, perturbation and observation, brushless DC electric motor, electronic commutation, voltage source inverter, centrifugal pump.

\section{INTRODUCTION}

Solar energy is one of the most attractive and effective renewable energy sources. This renewable energy source represents a good alternative solution to the conventional fuelfossil resources [15]. It reducesand minimizes the environmental problems in the world.Water pumping is one of the most applications of SPV array.It is used for farm irrigation especially in the rural areas, household drinking water supply, fish farms, and water supply to the industries. As known, induction motors are widely used in water pumping system due to its low cost construction, simple and lower maintenance. However, some of the imperfections of those motors, brush friction, when the speed is higher, the friction increases, then reducing useful torque and it's requires a complex control [5] and [13]. In the previous years, BLDC motors have become popular in many applications like robotics, medical instruments, and automobile industry. The advantages of brushless motors over induction motors include, long life, high efficiency and reliability, noiseless operation, high torque to-weight ratio, higher power density and smooth control of speed over a wide range. Due to all above paramount advantages, BLDC motor has been chosen to develop SPV fed water pump.

To achieve a maximum efficiency of the SPV array, a maximum power point tracking (MPPT) algorithm is used [17] and [25]. Numerous methods were proposed to track the maximum power point (MPP) in scientific articles. Each method is differed in terms of cost, efficiency and implementation. Perturb \& Observe (P\&O)MPPT method is used in this paper because of its fidelity of tracking even under the sudden change in the solar irradiation [21].

The structure of thispaper is as follows: First section provides the introduction of the paper. Section 2 describes the various stages of the studied system and section 3 deals with the design of the SPV array, DC-DC boost converter and the centrifugal pump, section 4 presents the control techniques of the system, section 5 shows the results and analysis through MATLAB/Simulink and the final section conclude this paper.

\section{SYSTEM CONFIGURATION DESCRIPTION}

Fig.1 depicts the schematic diagram of the studiedwater pumping system. From left to right, the studied system consists of a solar PV array, a DC-DC boost converter, a voltage source inverter (VSI), a BLDC motor and a centrifugal pump. In order to search the maximum power point, we use the $\mathrm{P} \& \mathrm{O}$ algorithm because of the simple arrangement and small measured parameters [26]. According to the rotor position of the BLDC motor, three hall signals are generated through the hall effect sensors, That are transformed later into six fundamental frequency switching pulses using electronic commutation. The design and control ofstudied system are elaborated in following sections. 


\section{DESIGN OFTHESTUDIED SYSTEM}

To operate the photovoltaic water pumping system under any kind of variation of solar irradiance, the different operating stages are designed as follows. The technical specifications of a selected BLDC motor of $1.32 \mathrm{~kW}$ rated power are indicated in Table III.

\section{A. Design of SPV Array}

The conversion of solar energy to electrical energy is done through solar PV cells. The equivalent circuit of a practical PV cell is shown in Fig. 2, which consists of a current source $I_{p h}$, a series resistance $R_{s}$ and a parallel resistance $R_{s h}$. The output current PV cell is given by the Equation. (1) and Equation. (2)[28].

$I_{P V}=I_{p h}-I_{\mathrm{d}}-I_{s h}$

$I_{P V}=I_{p h}-I_{\mathrm{s}} e^{\left(\frac{q\left(V_{P V}+I . R_{S}\right)}{n k T}\right)-1}-\frac{\left(V_{P V}+I \cdot R_{s}\right)}{R_{s h}}$

Where $I_{s}$ is the saturation current, $q$ is the electron charge $\left(1,6.10^{-19}(\mathrm{C})\right), k$ is Boltzmann constant $\left(1,38 \cdot 10^{-23}\left(\mathrm{~J}_{\mathrm{K}}{ }^{-1}\right)\right)$, $n$ is the diode ideality factor, $T$ is the PV cell temperature $(\mathrm{K})$.

To present the effect of irradiation variation, the PV panel model is simulated for different irradiation values at $T=$ $25^{\circ} \mathrm{C}$ and the $I-V$ and $P-V$ characteristics obtained are shown in Fig. 3.

In order to increase the output voltage and the output current, the PV cells are connected in series or parallel combinations to form solar arrays.

Concerning water pumping system, a solar PV array with peak power generating capacity of $\mathrm{P}_{\mathrm{mpp}}=1.38 \mathrm{KW}$ is chosen, more than the power required by the motor so that the performance of the system is not affected by the losses associated with the converters and the motor. The parameters of the SPV array are estimated at the standard solar irradiance of $1000 \mathrm{~W} / \mathrm{m}^{2}$. The estimation of the variousparameters to design a SPV array of appropriate size are given in Table I.

\section{B. Design of DC-DC Boost converter}

A DC-DC boost converter is used in this system Fig.4. It contains a boost inductor $(L)$, controlled switch (IGBT), diode and a filtering capacitor $(C)$. The inductor and capacitor of boost converter are designed according to the following equations [14].

$\Delta I_{L}=\frac{V_{i-\min } \cdot D}{f_{S} \cdot L}$

Where $V_{i-\min }$ is the minimum input voltage, $f_{s}$ the switchingfrequency, $D$ the duty cycle and $L$ is the inductor.
$L=\frac{V_{i}\left(V_{0}-V_{i}\right)}{\Delta I_{L} \cdot f_{S} \cdot V_{0}}$

Where $V_{i}$ is the input voltage, $V_{o}$ the output voltage, $f_{s}$ the switching frequency and $\Delta I_{L}$ the estimated inductor ripple current.

$C=\frac{I_{0} \cdot D}{\Delta V_{0} \cdot f_{s}}$

Where $C$ is the capacitor, $I_{0}$ the output current, $D$ the duty cycle, $f_{s}$ the switching frequency and $\Delta V_{0}$ the estimated output ripple voltage.

\section{Design of Water Pump}

Many varieties of pumps can be used in photovoltaic pumping systems, which are classified in two categories: centrifugal pump and positive displacement pumps. The centrifugal pump is the most widely used, it has a relatively high efficiency, inexpensive, simple, requires low maintenance and able to pump a high volume of water [3]. The performance of centrifugal pump can be predicted by three essential parameters, which are the total head $(\mathrm{H})$, flow rate $(\mathrm{Q})$, and hydraulic power $(\mathrm{P})$ which are given according to the following formulas[1].

$Q=\left(\frac{\omega}{\omega_{\text {ref }}}\right) \cdot Q_{\text {ref }}$

$H=\left(\frac{\omega}{\omega_{\text {ref }}}\right)^{2} \cdot H_{\text {ref }}$

$P=\left(\frac{\omega}{\omega_{\text {ref }}}\right)^{3} \cdot P_{\text {ref }}$

These laws stipulate that the flow rate is directly proportional to the wheel speed, the manometry height is proportional to the square of the speed and the hydraulic power is proportional to the cube of the speed.

The centrifugal pump applies a load torque proportional to the square of the rotational speed of the motor following relationship:

$T_{L}=K_{p} \cdot \omega^{2}$

Where $K_{p}$ is proportionality constant and $\omega$ is the rated speed of selected BLDC motor in $\mathrm{rad} / \mathrm{sec}$.

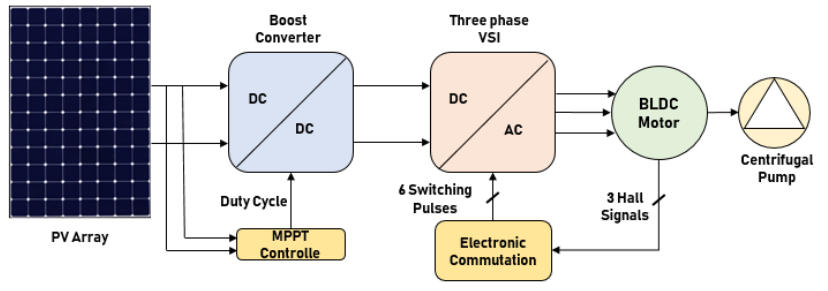

Fig.1. Block diagram of the BLOC water pumping system. 


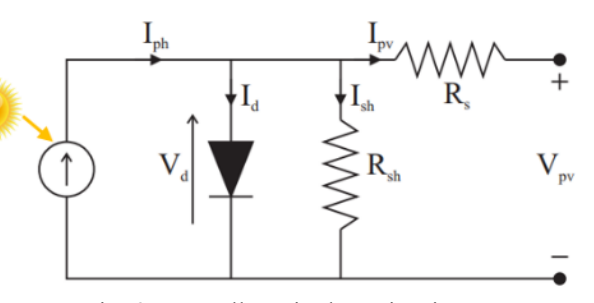

Fig. 2: PV cell equivalent circuit.

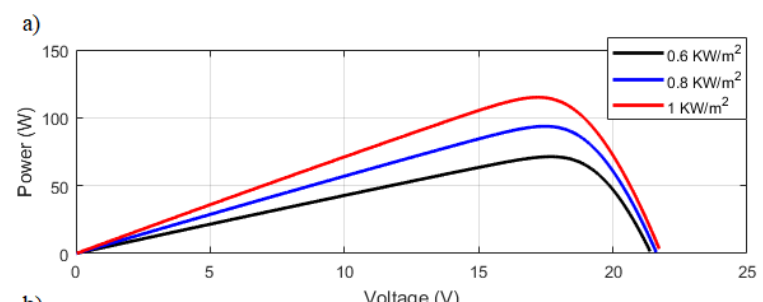

b)

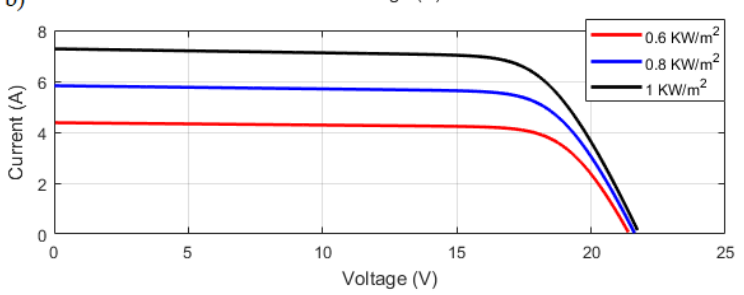

Fig. 3. a) P-V characteristics, b) I-V characteristics for different values of solar irradiation.

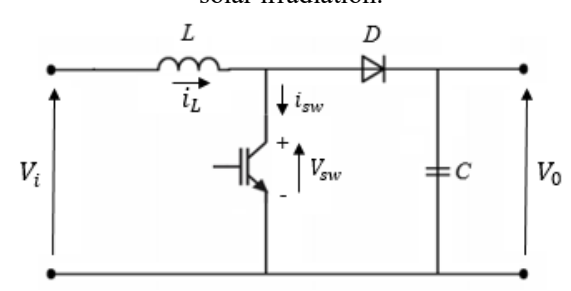

Fig.4.Schematic of DC-DC Boost converter.

TABLE I

DESIGN OF SOLAR PV ARRAY

\begin{tabular}{|l|l|}
\hline \multicolumn{2}{|c|}{ For a PV Module } \\
\hline Numbers of cells in a module & 36 \\
\hline Open circuit voltage & $21.8 \mathrm{~V}$ \\
\hline Short circuit current & $7.24 \mathrm{~A}$ \\
\hline Voltage at MPP, $V_{m}$ & $17.2 \mathrm{~V}$ \\
\hline Current at MPP, $I_{m}$ & $6.69 \mathrm{~A}$ \\
\hline \multicolumn{2}{|c|}{ For a PV Array } \\
\hline Voltage at MPP, $V_{m p p}=v_{p v}$ & $103.2 \mathrm{~V}$ \\
\hline Power at MPP, $P_{m p p}=p_{p v}$ & $1380.8 \mathrm{~W}$ \\
\hline Current at MPP, $I_{m p p}=i_{p v}$ & $P_{m p p} / V_{m p p}=1380.8 / 103.2=13.4 \mathrm{~A}$ \\
\hline Numbers of modules in series, $N_{s}$ & $V_{m p p} / V_{m}=103.2 / 17.2=6$ \\
\hline Numbers of modules in parallel, $N_{p}$ & $I_{m p p} / I_{m}=13.4 / 6.69=1.963 \approx 2$ \\
\hline
\end{tabular}

TABLE II

THE PROBABILITIES OF THE DIRECTION P\&O ALGORITHM

\begin{tabular}{|c|c|c|}
\hline$\Delta \boldsymbol{P}$ & $\Delta \boldsymbol{V}$ & Direction de perturbation \\
\hline+ & + & - \\
\hline+ & - & + \\
\hline- & + & + \\
\hline- & - & - \\
\hline
\end{tabular}

TABLE III

SPECIFICATIONS OF BLDC MOTOR

\begin{tabular}{|l|c|}
\hline Power, $P$ & $1.32 \mathrm{~kW}$ \\
\hline Speed, $N_{r}$ & $3000 \mathrm{rpm}$ \\
\hline DC voltage, $V_{d c}$ & $310 \mathrm{~V}$ \\
\hline No. of poles, $P$ & 4 \\
\hline Moment of inertia, $J$ & $2.9 \mathrm{~kg} . \mathrm{cm} 2$ \\
\hline Current, $I_{s}$ & $4.3 \mathrm{~A}$ \\
\hline Voltage constant, $K_{e}$ & $78 \mathrm{~V} / \mathrm{krpm}$ \\
\hline Torque constant, $K_{t}$ & $0.74 \mathrm{Nm} / \mathrm{A}$ \\
\hline phase/phase resistance, $R_{s}$ & $3.58 \Omega$ \\
\hline phase/phase inductance, $L_{s}$ & $9.13 \mathrm{mH}$ \\
\hline
\end{tabular}

TABLE IV

SWITCHING STATES OF VSI BASED ON HALL-EFFECT SIGNAL STATES

\begin{tabular}{|c|c|c|c|c|c|c|c|c|c|}
\hline \multirow{2}{*}{$\theta\left({ }^{\circ}\right)$} & \multicolumn{3}{|c|}{ Hall Signals } & \multicolumn{7}{|c|}{ Switching States } \\
\cline { 2 - 11 } & $\mathrm{H}_{3}$ & $\mathrm{H}_{2}$ & $\mathrm{H}_{1}$ & $\mathrm{~S}_{1}$ & $\mathrm{~S}_{2}$ & $\mathrm{~S}_{3}$ & $\mathrm{~S}_{4}$ & $\mathrm{~S}_{5}$ & $\mathrm{~S}_{6}$ \\
\hline $\mathrm{NA}$ & 0 & 0 & 0 & 0 & 0 & 0 & 0 & 0 & 0 \\
\hline $0-60$ & 1 & 0 & 1 & 1 & 0 & 0 & 1 & 0 & 0 \\
\hline $60-120$ & 0 & 0 & 1 & 1 & 0 & 0 & 0 & 0 & 1 \\
\hline $120-180$ & 0 & 1 & 1 & 0 & 0 & 1 & 0 & 0 & 1 \\
\hline $180-240$ & 0 & 1 & 0 & 0 & 1 & 1 & 0 & 0 & 0 \\
\hline $240-300$ & 1 & 1 & 0 & 0 & 1 & 0 & 0 & 1 & 0 \\
\hline $300-360$ & 1 & 0 & 0 & 0 & 0 & 0 & 1 & 1 & 0 \\
\hline $\mathrm{NA}$ & 1 & 1 & 1 & 0 & 0 & 0 & 0 & 0 & 0 \\
\hline
\end{tabular}

\section{CONTROL OF STUdied SySTEM}

In the studied system, the P\&O-MPPT aims at controlling SPV array and electronic commutation of BLDC motor to control the voltage source inverter (VSI), in the following sections the control methods are explained as follows.

\section{A. Maximum Power Point Tracking (MPPT)}

The P\&O algorithm is most widely used for PV-MPPT due to its low cost and very simple structure and small measured parameters [13], [15] and [16]. The chart implementation of $\mathrm{P} \& \mathrm{O}$ method is given in Fig.5.

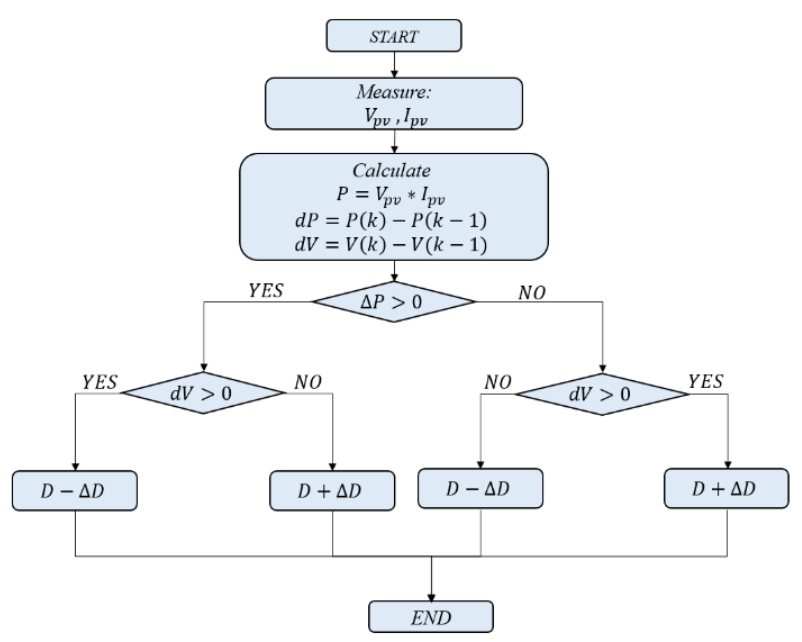

Fig.5. Stateflow chart of the perturb-and-observe algorithm. 
As the name denote ,the approach of this method is based on calculating the PV power by measuring the sensed values of the voltage and current andcomparedthem with the precedent power and voltage, then the direction of the algorithm is adjusted. The duty cycle of the boost converter is adjusted as in Equation 10, [20]:

$D_{k+1}=D_{k} \pm \Delta D$

Where $D_{k}$ and $D_{k+1}$ are the previous and the next perturbation of duty cycle respectively, $\Delta D$ is the constant width of the step size.The probabilities of the direction $\mathrm{P} \& \mathrm{O}-\mathrm{MPPT}$ algorithm are explained in Table II.

\section{B. Electronic Commutation}

In order to generate the switching signals for the VSI, electronic commutation of the BLDC motor is used. The encoder provides three Hall Effect signals (H1, H2, and H3) following the angular position of the rotor, which are further converted logically into six switching pulses (S1, S2, S3, S4, S5 and S6) then used to operate the six IGBT switches of the VSI, [2], [5] and [7]. Table VI shows the possible switching states of the VSI feeding a BLDC motor.

\section{RESULTS \& DISCUSSION}

The system described in Fig.1was simulated in MATLAB/Simulink environment. The performance of studied system in the starting, dynamic and steady state under different solar insolation levels are evaluated using the simulated results shown in Figs.6-11.

\section{A. Starting and Steady State Performances of Studied system at constant Solar Irradiance of $1000 \mathrm{~W} . \mathrm{m}^{-2}$}

The various performance indices of SPV array boost converter and BLDC motor under starting and steady state at the standard solar irradiance of $1000 \mathrm{~W} / \mathrm{m}^{2}$, are illustrated in Figs.6-8, and elaborated in the following subsections.

1) Performance of SPV array:Fig.6 show the power generated by the PV array under the steady state condition of irradiance of $1000 \mathrm{~W} \cdot \mathrm{m}^{-2}$. It corresponds to the operation of the SPV array at MPP as PV power reaches $1380 \mathrm{~W}$ at steady state.

2) Performance of boost converter: The behavior of theboost converter at $1000 \mathrm{~W} / \mathrm{m}^{2}$ are shown in Fig. 7.Where the DC link voltage, $V_{d c}$, the inductor current, $i_{L}$, voltage stress on the switch, $V_{s w}$, and current stress on the switch, $i_{s w}$, are presented. $V_{d c}$ reaches the rated DC voltage of BLDC motor i.e. $310 \mathrm{~V}$.

3) Performance of BLDC motor-pump: Performance and behaviors of the BLDC motor at steady state irradiance of $1000 \mathrm{~W} / \mathrm{m}^{2}$ connected to the centrifugal pump are shownin Figs. 8. The variables viz.theback $\mathrm{EMF}, e_{a}$, the current, $i_{s a}$, the electromagnetic torque, $T_{e}$, the load torque, $T_{L}$, and the speed, $N$, reach their rated values under steady state as MPP is tracked. The small pulses of $T_{e}$ results from the electronic commutation of BLDC motor. The starting current of BLDC motor is bounded within the permissible range hence the motor has a soft start.
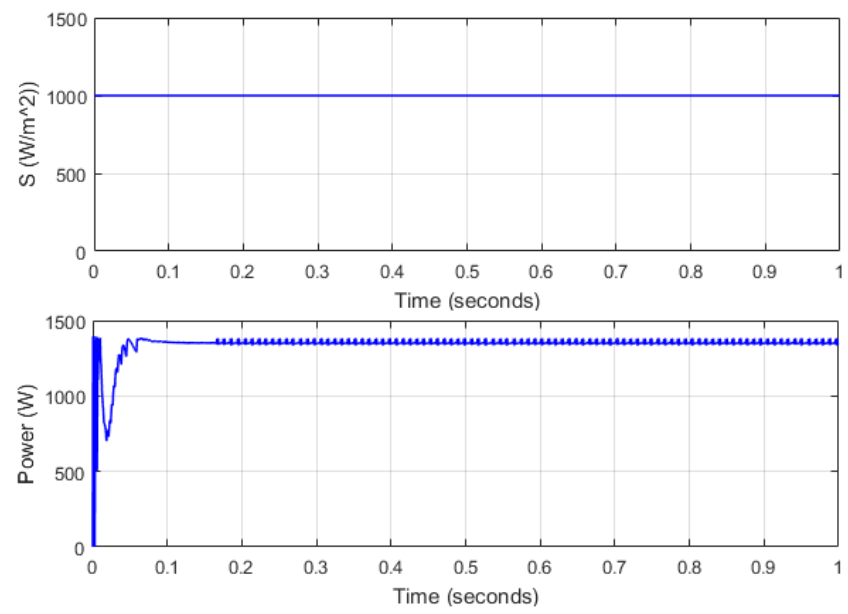

Fig.6.Starting and steady state performance of SPV array at $1000 \mathrm{~W} / \mathrm{m}^{2}$.
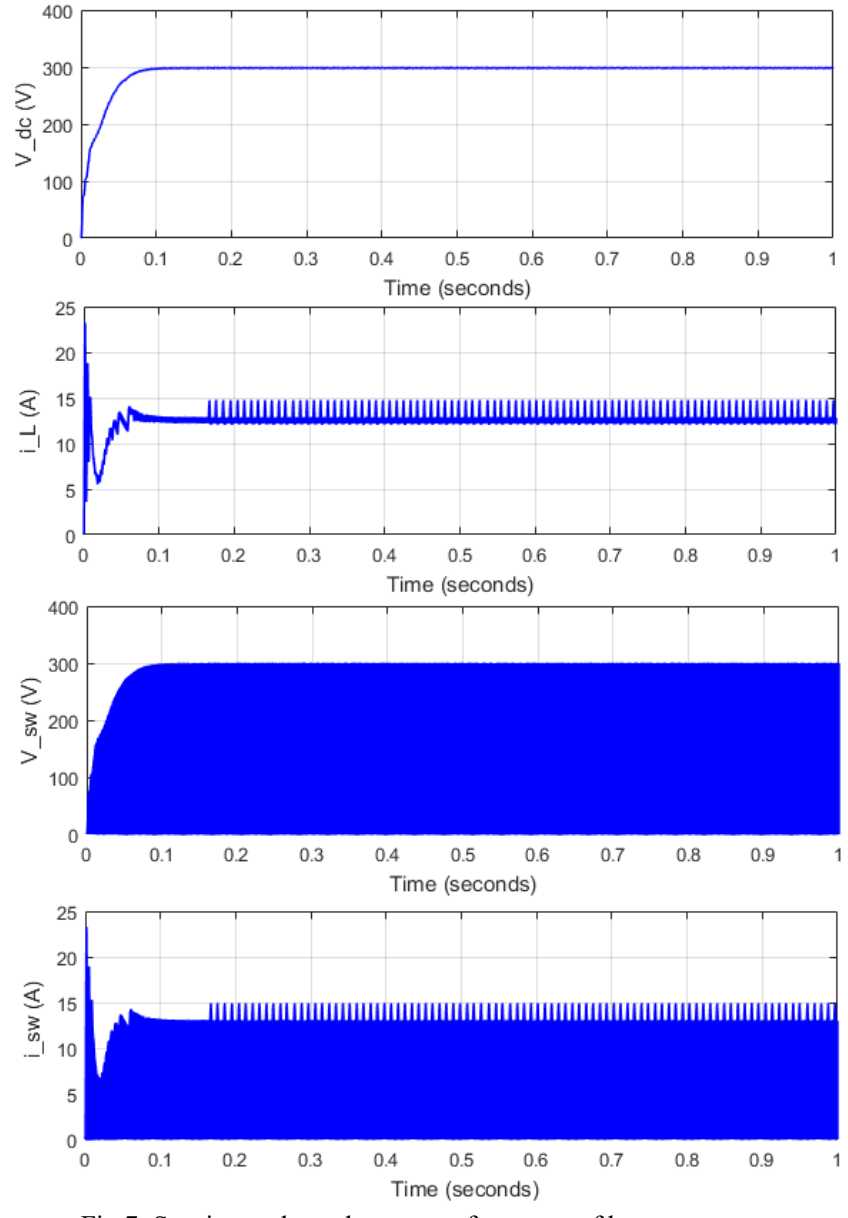

Fig.7. Starting and steady state performance of boost converter at $1000 \mathrm{~W} / \mathrm{m}^{2}$ 

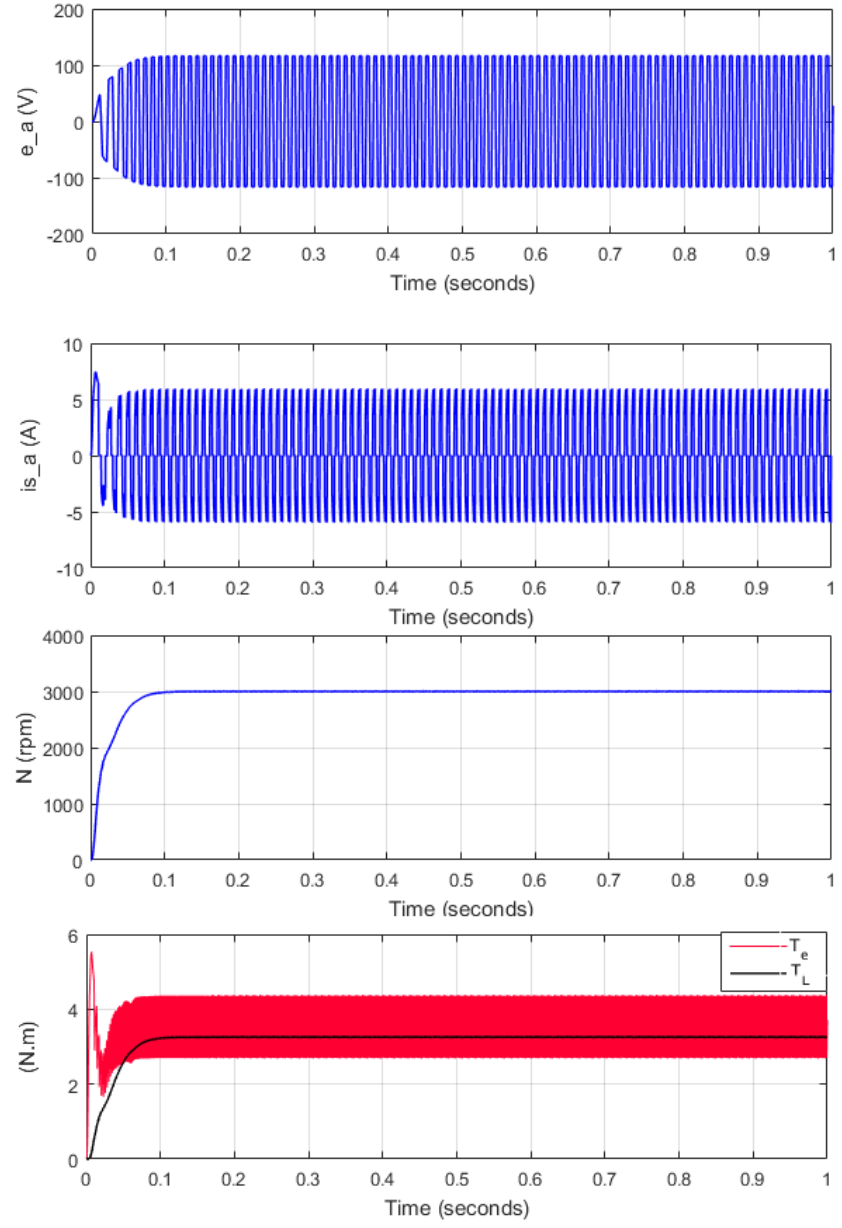

Fig.8.Starting and steady state performance of BLDC motor - pump at $1000 \mathrm{~W} / \mathrm{m}^{2}$.

\section{B. Dynamic Performances of Studied System}

To verify the performance of the studied system in dynamic state, the solar insolation level has been varied dynamically in three steps, $600 \mathrm{~W} / \mathrm{m}^{2}$ from 0 to $1 \mathrm{~s}, 1000 \mathrm{~W} / \mathrm{m}^{2}$ from 1 to $2 \mathrm{~s}$, and $800 \mathrm{~W} / \mathrm{m}^{2}$ from 2 to $3 \mathrm{~s}$. The various performance indices of SPV array, DC-DC boost converter and BLDC motor are illustrated in Figs. 9.11.

1) Performance of SPV array:Fig. 9 show the power generated by the SPV with the solar irradiance changing from $200 \mathrm{~W} / \mathrm{m}^{2}$ to $1000 \mathrm{~W} / \mathrm{m}^{2}$ and then to $800 \mathrm{~W} / \mathrm{m}^{2}$. The SPV array, at MPP, changes its operating point from $848 \mathrm{~W}$ to $1380 \mathrm{~W}$ and then to $1114 \mathrm{~W}$.

2) Performance of boost converter: The dynamicbehavior of boost converter is presented in Fig. 10. The inductor current, $i_{L}$, DC link voltage, $V_{d c}$, voltage stress on the switch, $V_{S w}$, and current stress on the switch, $i_{s w}$, are presented. The DC link voltage $V_{d c}$ alters from $245 \mathrm{~V}$ to $310 \mathrm{~V}$ and then to $275 \mathrm{~V}$ as the solar irradiance varies from $600 \mathrm{~W} / \mathrm{m}^{2}$ to $1000 \mathrm{~W} / \mathrm{m}^{2}$ and then to $800 \mathrm{~W} / \mathrm{m}^{2}$.

3) Performance of BLDC motor-pump: Fig. 11presents the dynamic behaviors of the BLDC motor-pump. All the motor indices such as the back EMF, $e_{a}$, the stator current, $i_{s a}$, the speed, $N$, the electro-magnetic torque,
$T_{e}$ and the load torque offered by pump, $T_{L}$ follows the variation in solar irradiance and reach their steady state values as MPP is tracked. The speed increases from 2560 rpm to $3000 \mathrm{rpm}$ and then to 2800 , these speeds are sufficient to pump the water, although not with the full capacity. The BLDC motor develops the electromagnetic torque, $T_{e}$ equal to the torque required to drive the pump, $T_{L}$. This performance implies that the studied water pumping system operates successfully even in different solar irradiance.
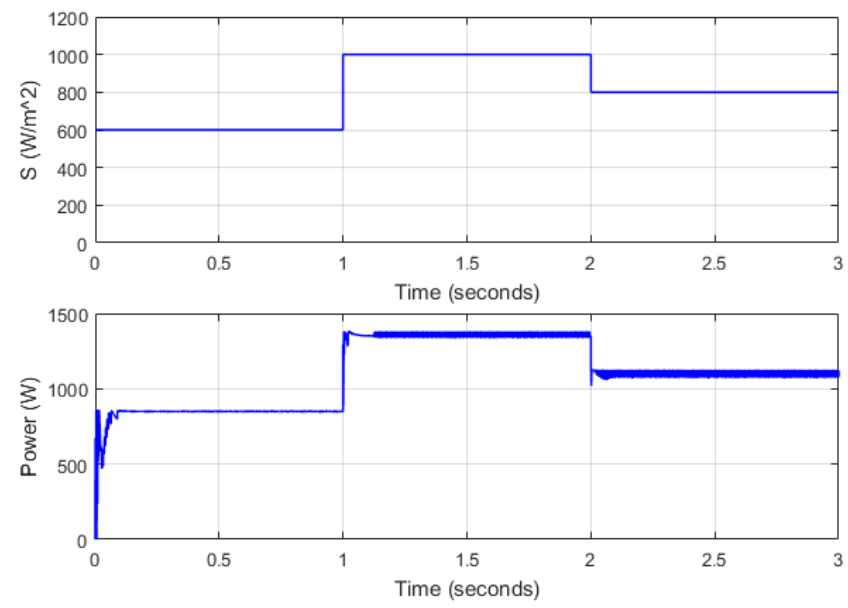

Fig.9 Dynamic performance of SPV array.
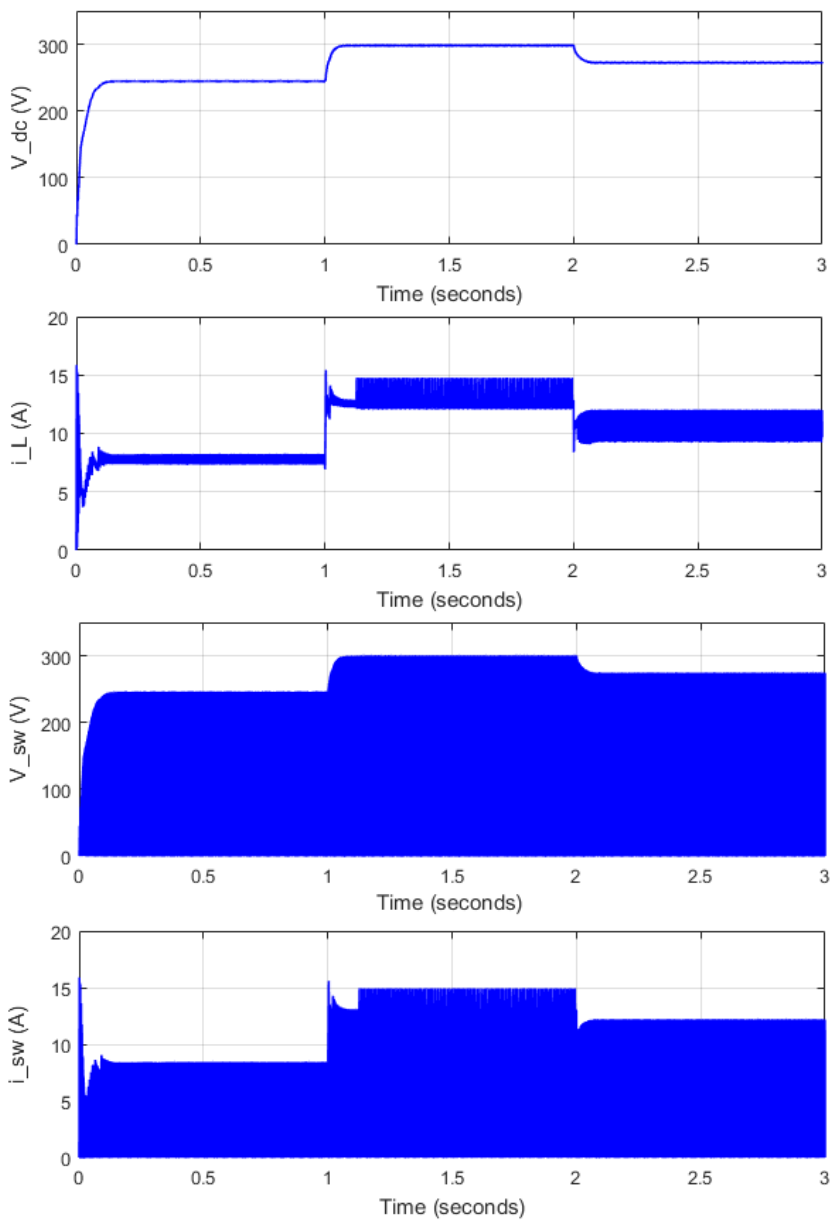

Fig.10 Dynamic performance of boost converter. 

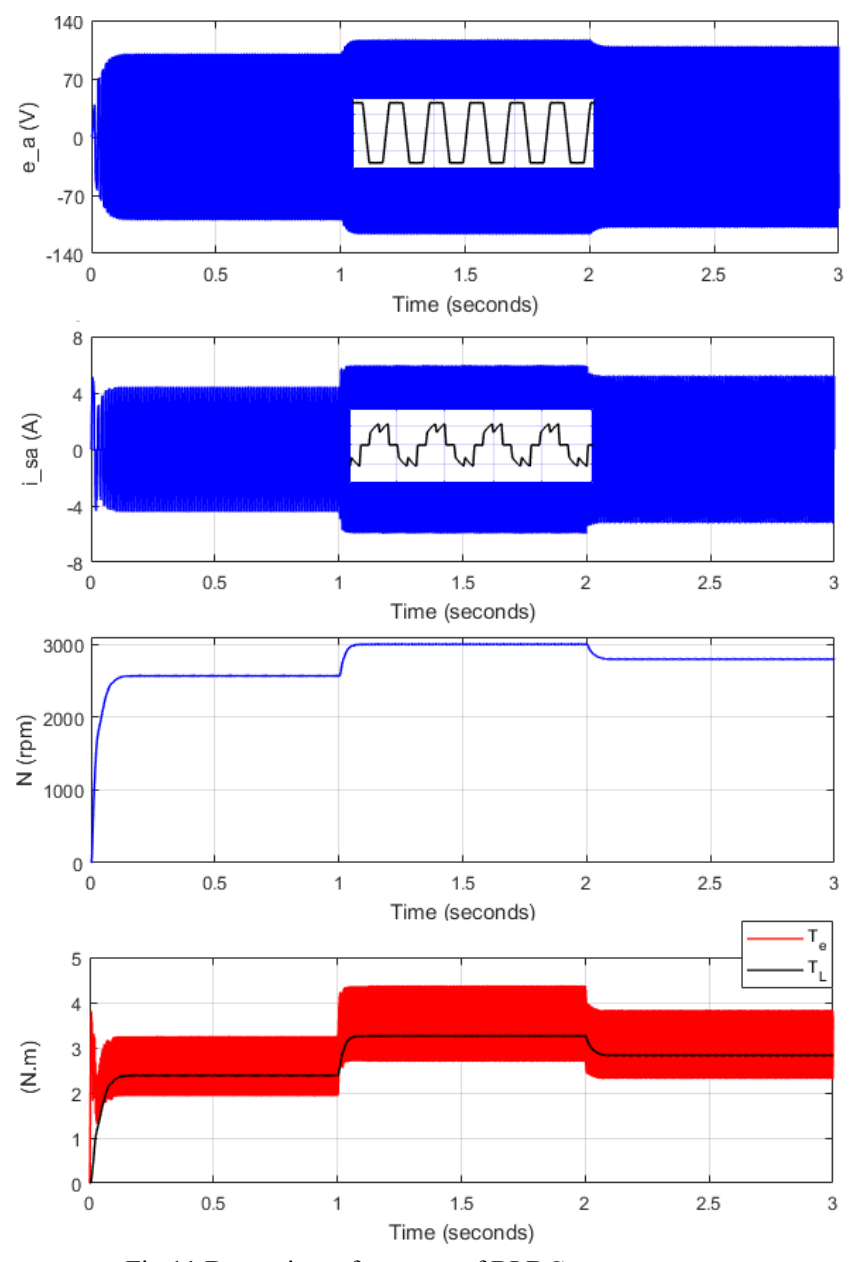

Fig.11 Dynamic performance of BLDC motor - pump.

\section{CONCLUSIONS}

The main objective of the studied system has been affirmed by performance evolutions under different solar irradiation levels. The DC-DC boost converter, has been chosen because of the good conversion efficiency and it's more suitable for the studied water pumping system. The speed of BLDC motor is controlled by variable DC link voltage and the soft starting of the motor is obtained by wisely tracking the MPP and electronic commutation with fundamental frequency switching.

\section{REFERENCES}

[1] Ouada, M., Meridjet, M. S., \&Talbi, N. (2013, March). Optimization photovoltaic pumping system based BLDC using fuzzy logic MPPT control. In 2013 International Renewable and Sustainable Energy Conference (IRSEC) (pp. 27-31). IEEE.

[2] Kumar, R., \& Singh, B. (2014, December). Solar PV array fed cuk converter-VSI controlled BLDC motor drive for water pumping. In 2014 6th IEEE Power India International Conference (PIICON) (pp. 1-7). IEEE.

[3] Kumar, R., \& Singh, B. (2014, December). Buck-boost converter fed BLDC motor drive for solar PV array based water pumping. In 2014 IEEE International Conference on
Power Electronics, Drives and Energy Systems (PEDES) (pp. 1-6). IEEE.

[4] Kommula, B. N., \& Kota, V. R. (2018). A novel scheme for torque ripple minimization of BLDC motor used in solar air conditioner. Electrical Engineering, 100(4), 2473-2483.

[5] Kumar, R., \& Singh, B. (2015, December). BLDC motor driven water pump fed by solar photovoltaic array using boost converter. In 2015 Annual IEEE India Conference (INDICON)(pp. 1-6). IEEE.

[6] Ouada, M., Meridjet, M. S., Saoud, M. S., \& Derradji, N. (2014, November). Study of new configuration photovoltaic pumping system. In 2014 International Conference on Electrical Sciences and Technologies in Maghreb (CISTEM) (pp. 1-5). IEEE.

[7] Kumar, R., \& Singh, B. (2014, December). Solar photovoltaic array fed Luo converter based BLDC motor driven water pumping system. In 2014 9th International Conference on Industrial and Information Systems (ICIIS) (pp. 1-5). IEEE.

[8] Elminir, H. K., Ghitas, A. E., Hamid, R. H., El-Hussainy, F., Beheary, M. M., \& Abdel-Moneim, K. M. (2006). Effect of dust on the transparent cover of solar collectors. Energy conversion and management, 47(18-19), 3192-3203.

[9] Chandrasekaran, N., \& Thyagarajah, K. (2012, March). Comparative study of photovoltaic pumping system using a DC motor and PMDC motor. In IEEE-International Conference On Advances In Engineering, Science And Management (ICAESM-2012) (pp. 129-132). IEEE.

[10] Sontake, V. C., \& Kalamkar, V. R. (2016). Solar photovoltaic water pumping system-A comprehensive review. Renewable and Sustainable Energy Reviews, 59, 1038-1067.

[11] Banu, I. V., Beniugă, R., \& Istrate, M. (2013, May). Comparative analysis of the perturb-and-observe and incremental conductance MPPT methods. In 2013 8th International Symposium on Advanced Topics in Electrical Engineering (ATEE) (pp. 1-4). IEEE.

[12] Niapour, S. K. M., Danyali, S., Sharifian, M. B. B., \& Feyzi, M. R. (2011). Brushless DC motor drives supplied by PV power system based on Z-source inverter and FL-IC MPPT controller. Energy Conversion and Management, 52(8-9), 3043-3059.

[13] Depuru, Shobha Rani, and Muralidhar Mahankali. "Boost converter fed high performance BLDC drive for solar PV array powered air cooling system." (2017).

[14] Yilmaz, U., Kircay, A., \& Borekci, S. (2018). PV system fuzzy logic MPPT method and PI control as a charge controller. Renewable and Sustainable Energy Reviews, 81, 994-1001.

[15] Ahmed, J., \& Salam, Z. (2016). A modified P\&O maximum power point tracking method with reduced steady-state oscillation and improved tracking efficiency. IEEE Transactions on Sustainable Energy, 7(4), 1506-1515.

[16] Nigam, A., \& Gupta, A. K. (2016, October). Performance and simulation between conventional and improved perturb \& observe MPPT algorithm for solar PVcell using MATLAB/Simulink. In 2016 International Conference on Control, Computing, Communication and Materials (ICCCCM) (pp. 1-4). IEEE. 
[17] Gupta, A. K., Gupta, M., \& Saxena, R. (2018). Modeling and Comparative Analysis of PV Module with Improved Perturbation \& Observation Based MPPT Technique for PV Applications. Archives of Current Research International, 112.

[18] Jain, S., Thopukara, A. K., Karampuri, R., \& Somasekhar, V. T. (2014). A single-stage photovoltaic system for a dualinverter-fed open-end winding induction motor drive for pumping applications. IEEE Transactions on power Electronics, 30(9), 4809-4818.

[19] Singh, B., \& Bist, V. (2014). A BL-CSC converter-fed BLDC motor drive with power factor correction. IEEE Transactions on Industrial Electronics, 62(1), 172-183.

[20] Al-Majidi, S. D., Abbod, M. F., \& Al-Raweshidy, H. S. (2018). A novel maximum power point tracking technique based on fuzzy logic for photovoltaic systems. International Journal of Hydrogen Energy, 43(31), 14158-14171.

[21] Rebei, N., Gammoudi, R., Hmidet, A., \& Hasnaoui, O. (2014, February). Experimental implementation techniques of P\&O MPPT algorithm for PV pumping system. In 2014 IEEE 11th International Multi-Conference on Systems, Signals \& Devices (SSD14) (pp. 1-6). IEEE.

[22] Motahhir, S., El Hammoumi, A., \& El Ghzizal, A. (2018). Photovoltaic system with quantitative comparative between an improved MPPT and existing INC and P\&O methods under fast varying of solar irradiation. Energy Reports, 4, 341-350.

[23] Terki, A., Moussi, A., Betka, A., \& Terki, N. (2012). An improved efficiency of fuzzy logic control of PMBLDC for PV pumping system. Applied Mathematical Modelling, 36(3), 934-944.

[24] Periasamy, P., Jain, N. K., \& Singh, I. P. (2015). A review on development of photovoltaic water pumping system. Renewable and Sustainable Energy Reviews, 43, 918-925.

[25] Eltawil, M. A., \& Zhao, Z. (2013). MPPT techniques for photovoltaic applications. Renewable and sustainable energy reviews, 25, 793-813.

[26] Nigam, A., Gupta, A. K., \& Sharma, S. (2016). Simulation of modified P\&O MPPT technique for solar PV cell using MATLAB/SIMULINK. International Research Journal of Engineering \& Technology, 3(4).

[27] Abdourraziq, S., \& El Bachtiri, R. (2017). A Comparative Study Between Photovoltaic Pumping Systems Using a Permanent Magnet DC Motor and an Induction Motor. In Mediterranean Green Buildings \& Renewable Energy (pp. 89-101). Springer, Cham.

[28] Motahhir, S., El Hammoumi, A., \& El Ghzizal, A. (2018). Photovoltaic system with quantitative comparative between an improved MPPT and existing INC and P\&O methods under fast varying of solar irradiation. Energy Reports, 4, 341-350. 